\title{
The fiscal policy and economic growth of Kosovo: An econometrical analysis
}

\section{Besime Ziberi (iD, Adelina Hodaj}

Faculty of Economics, AAB College, Kosovo

Email: besime.ziberi@universitetiaab.com; adelina.hodaj@universitetiaab.com

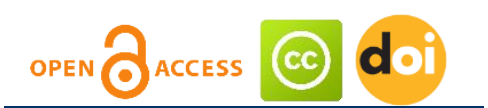

Article history:

Received: July 10, 2020

1st Revision: August 23, 2020

Accepted: October 31, 2020

\section{JEL classification: E60 \\ 011}

DOI:

10.14254/jems.2020.5-2.8

\begin{abstract}
The fiscal policy plays a crucial role in a country's economic growth and development. The main aim of this paper is to analyze the fiscal policy in general and to estimate the impact of direct and indirect taxes on economic growth in particular in case of Kosovo. To achieve the main aim of this paper a broadly national and international literature is reviewed and discussed thus the Pearson Correlation and Ordinary Least Square (OLS) regression model have been modified and adapted to estimate the relationship and the impact of direct and indirect taxes on economic growth in Kosovo. The data used is secondary data taken from the Tax Administration of Kosovo, the Ministry of Finance and the Kosovo Agency of Statistics. For model estimation the IBM SPSS program is used. This study concludes that budget revenues from direct and indirect taxes mark an increasing and positive trend in case of Kosovo. Based on the Pearson Correlations we conclude that direct taxes are strongly and positively correlated to Gross Domestic Product however the results of OLS regression in our circumstances show no significance of the independent variables that means that direct and indirect taxes have no impact on economic growth of Kosovo. The paper comes with some key conclusions and further recommendations.
\end{abstract}

Keywords: fiscal policies, Kosovo Tax Administration (TAK), tax system, economic growth. 


\section{Introduction}

The goals of tax policy are usually to provide a fair, efficient and predictable way of financing government spending. To achieve these multiple objectives, policymakers choose a tax mix. Separately, each tax has its own characteristics of fairness, efficiency and predictability. In this light, the tax system of Kosovo is based and developed on the best international practices. Since the end of the Kosovo war, reconstruction efforts have been aimed at putting the Kosovo economy on the path of development. Progresses in reconstruction, macroeconomic stability and the establishment of public institutions have been able to improve economic activity since 2001 (Ziberi \& Avdiu, 2020). Where Kosovo's economy has grown steadily, even during the economic crisis, inflation has been kept under control, public debt is low, and banking sector indicators are sound. Thanks to rapidly increasing fiscal revenues and reserves accumulated earlier, when the crisis arose, Kosovo was able to adapt a counter-cyclical fiscal policy. With the adoption of a new fiscal rule, the purpose of which was to ensure that Kosovo's fiscal deficit and public debt are maintained at stable levels in the future. During this time period (2008-2013), public expenditures were strongly focused on capital expenditures which were focused on investments in infrastructure projects, which helped to support economic growth.

In addition to the positive aspect, the country's fiscal policy also addresses issues of efficiency and allocations. During this time there was a tendency to over-invest in new assets and to underinvest in the maintenance of existing assets, a special issue in the case of roads, but also many schools need improvements and some new health buildings are poorly built. In addition, investments in education and health were lower than needed to be invested.

The tax system in Kosovo has evolved from the system of UNMIK Regulations, to the system of tax laws issued by the Assembly of the Republic of Kosovo, which meet international standards and materialize the principles of the EU. These laws are considered to be understandable and easy to administer and implement. The Compliance Strategy will be implemented in the context of economic growth, which in itself has a positive impact on revenue collection (Kosovo Tax Administration, 2000).

The properties of each tax and the interaction between taxes determine the characteristics of the tax system. In particular, we see state policymakers having preferences over the characteristics of the tax system, which in turn generate a demand for specific taxes. The desired tax mix will vary from state to state, both due to changes in policy preferences and due to changes in states in the characteristics of individual taxes and the way they interact with the state economy (Gentry \& Ladd, 1994).

Pursuant to Article 2 (Tax Administration of Kosovo, 2014), TAK is an administrative unit which has the status of an Executive Agency, and operates in full operational autonomy within the Ministry of Finance and Economy of Kosovo. In a study from Krasniqi (2016) is stated that the implementation of fiscal policies is dependent on the correctness of the policy which affects its reflection in the economic and social environment. In every country of the tax system, the support of governments is needed in promoting revenue growth, where the latter is needed for the formation of the state budget. Gjokutaj (2019) stated that with the adoption of a policy that addresses the real situation of the country, as well as of each of its municipalities, the goals of the country's economic policies can be achieved. It is also said that it is natural that fiscal policy has a direct impact on the construction of the country's budget, which is achieved through tax, customs and local policy in the social aspect. Given this effect, fiscal policy should stimulate the response of the economic environment, where increasing budget revenues stimulate the development and growth of business activities, where through it stimulates economic growth, and vice versa.

\section{Literature review}

The report on the review of public finances of Kosovo (Demakaj, 2014) emphasizes the fact that Kosovo is the youngest country in Europe, both in terms of history and demographics. As part of the former Yugoslavia, which was Kosovo, it became a separate territory under United Nations administration in 1999, and declared its independence in 2008.

According to (Stiglitz J. , 2014) like any other system the tax system has its own characteristics. Characteristics of tax system according to the author in question are: economic effectiveness; Administrative simplicity; flexibility; Political accountability; Tax justice. 
Financial stability is defined in terms of its ability to facilitate and strengthen economic processes, risk management and shock absorption. Moreover, financial stability is considered continuity: variable over time and consistent with multiple combinations of constituent elements of finance. The paper also discusses some practical implications of the definition that should be considered when using it for policy analysis or designing an analytical framework (Schinasi, 2004)

Mark and Asmaa (2009) stated that fiscal policy is the use of government spending and taxes to influence the economy. Governments typically use fiscal policy to promote strong and sustainable growth and reduce poverty. The role and objectives of fiscal policy have gained importance in the current crisis as governments have stepped in to support financial systems, increase start-ups and mitigate the impact of the crisis on vulnerable groups. In a statement after their summit in London in April, the leaders of the Group of Twenty industrialized and emerging market countries stated that they were undertaking "unprecedented and unified fiscal expansion".

The prominent author (Musgrave, 1959), stated three main functions of the fiscal system:

- Distribution function - Financing of offers of public goods and services;

- Stabilization Function - Action at the level of aggregate demand;

- Redistributive function - Distribution of income among residents with income differences. According to (Samuelson, 1954), fiscal policies serve to determine the needs for taxation and to determine public expenditures through the process of preventing the downturn of the local economy and maintaining such a state in the economy or its growth and employment growth without major impacts on inflation and deflation.

Meanwhile (Hayek, 1932) in one of his books emphasizes the important fact of the interaction of fiscal and monetary policies in the economy, where according to the study the combination of both these measures, gives more effective results. In order to achieve the best effects for the economy of a country, an interaction of both fiscal and monetary measures is needed, so no measure should be underestimated that is less important than the other measure that can be applied by the state at different times either for the purpose of economic growth or to influence the conditions of the recession in the economy.

Various fiscal policy researchers have analyzed the impact of these fiscal policies on the conditions of different economic cycles, as a result of an economic growth at a given time or a reduction of the economy in another period. In this way (Aghion \& Marinescu, 2008) and (Woo, 2009) have presented two papers based on which they have examined how fiscal policy affects production and both papers show that pro cyclical fiscal policy increases can hurt long-term growth. Economic and production instability therefore consider that fiscal policies should be consistent and not just implemented as a result of different economic cycles.

The state considers various measures to be taken for coverage when it is in conditions of budget deficit, measures which can be of fiscal, monetary or combined character. Through the change of tax rates, the state can apply the adjustments to the measures of fiscal character, applying their increase and reducing the budget expenditures, but there is also the possibility of covering this deficit through public debts both inside and outside the country. However, they analyze how restrictive fiscal policies affect the state budget and its impact on consumption in the household economy (Bertola \& Drazen, 1993), where according to them the restrictive budget policy causes expectations for a reduction of taxes in the future and a higher value high current household income, which this reduction stimulates private consumption and thus affects the growth of production.

We can say that the primary goal of adequate fiscal policies is to cover budget expenditures, but as stated above by other studies, this coverage by governments can be done through raising tax rates or public debts. But that this increase in tax rates may affect the unequal distribution of income and may violate the principle of equality in taxes as a basic principle, which is also associated with social justice (ranging from the use of public goods to distribution of income). Therefore, many authors have written about the impact of fiscal policies on the material goods of a state and the way they are distributed, but one of the most important of the modern period is (Stiglitz \& Boadway, 1994) who together stated that "Goods public goods are those goods that do not constitute any additional cost for an individual to enjoy them and require a great deal to exclude any individual from enjoying them, so they are not excluded from their use. The public good is protection."

According to (Spilimbergo, Schindler, \& Symansky, 2009) of great importance are the multiplier effects of fiscal policies, the effect of which is seen in consumption and investment at both government level and their distribution for household consumption therefore based on article the effects are usually greater for government consumption, public investment and distribution to households, while they are relatively small for indirect taxes. 
On the other hand (Barro \& Sala-I-Martin, 1992) emphasize that fiscal policies can affect stimulus and economic growth if applied properly otherwise if applied incorrectly they will affect and delay growth therefore, both the allocation of funds for capital investment and investments in professional capacity building can be affected by taxes and government expenditures. Whereas (Alesina \& Ardagna, 1998), emphasize that through the adjustment of fiscal policies are used mainly in spending cuts and especially in the salaries of government officials and various distributions, while when fiscal policies are restrictive then we have the characterization of raising tax rates.

\section{Research methodology and data}

This study analyze a broadly literature related fiscal policy, taxes and economic growth. The data used are secondary data taken from Kosovo Tax Administration, Ministry of Finance of Kosovo and Kosovo Agency of Statistics. The data used cover the time period 2009-2019. The model used is multiple regression Ordinary Least Square (OLS) and Pearson Correlation. The conceptual variables are Gross Domestic Product (GDP), Direct and Indirect taxes. For model estimation we have used the IBM SPSS.

The Ordinary Least Square Regression (OLS) method is the simplest method for analysis and is an approximate estimator of the conditional mean of the dependent variable when we have data on one or more independent variables. OLS was first introduced by the French mathematician Legendre (1805) and 'Regression' as a term was introduced by Galton and later validated by Pearson, known for the law of universal regression of human length (Douglas, Elizabeth., \& Geoffrey, 2012).

In econometrics, the small squares method (OLS) is widely used to estimate the parameter of a linear regression model. OLS estimators, minimize the amount of errors per square (a difference between observed values and predicted values). While OLS enables easy calculation and use when performing any econometrics test, the basic assumptions of OLS regression are quite important. This is because a lack of knowledge on OLS assumptions will result in its misuse and will give inaccurate results for the completed econometrics test.

According to the number of variables included in the model we distinguish:

Simple Regression (One Factor) - Simple regression is assumed to be a real relationship between $\mathrm{Y}$ and $\mathrm{X}$ for all the possible values they can take to and is known as the population regression function. This regression takes the form:

$$
\gamma_{i}=\beta_{0}+\beta_{1} X 1+\mu_{i}
$$

This formula contains the constant, the explanatory variables and the random error.

Multiple Regression - If we add more variables to the model it is understood that more variation of the dependent variable will be explained (Douglas, Elizabeth., \& Geoffrey, 2012). In our concrete case we have constructed the multifactorial regression model which takes the following form and below the study are presented the equations with concrete values of the model based on the study. The multiple regression formula takes the following form:

$$
\gamma=\beta_{0}+\beta_{1} X_{1}+\beta_{2} X_{2}+\beta_{3} X_{3}+\ldots \beta_{n} X_{n}+\mu
$$

In the following section we interpret the results and discuss the findings.

\section{Results and discussions}

In the section four we present trend of GDP in case of Kosovo giving so the answer how tax system affects economic growth via Pearson Correlation and OLS model 
Graph 1: Economic growth during the period 2010-2018

GDP Growth rate in case of Kosovo

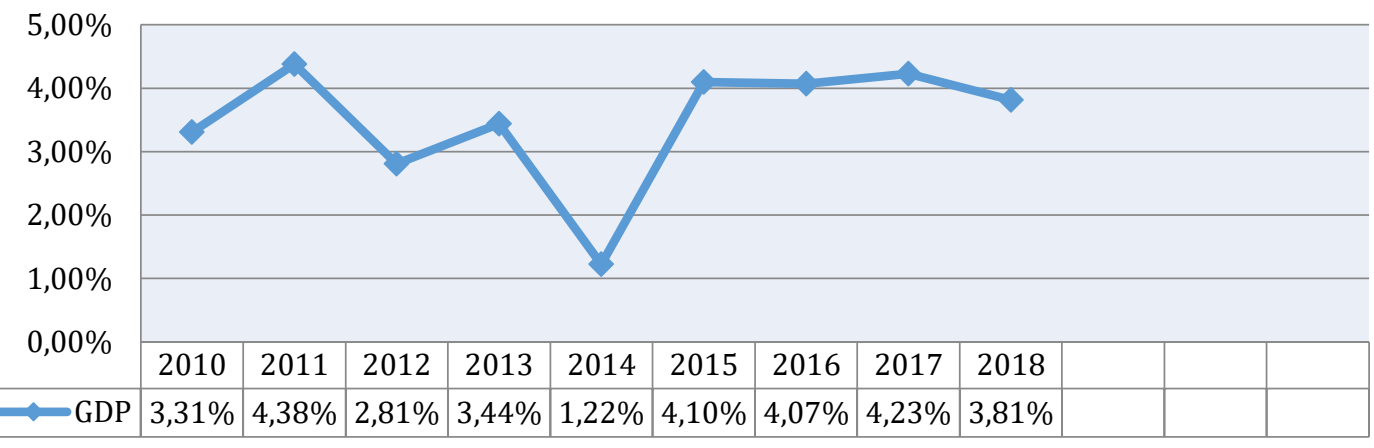

Source: Author's calculations - Secondary data from World Bank annual reports https://data.worldbank.org/indicator/NY.GDP

The data presented in the graph one shows the trend of GDP growth in Kosovo during the time period 2010-2018.. The lowest economic growth recorded is that of 2014 of $1.22 \%$ while the highest is of 2011 of $4.38 \%$. While the largest growth of the economy was that from 2014 to 2015 where from $1.22 \%$, economic growth reaches $4.10 \%$ so this year was realized growth of $2.88 \%$. A very small increase of $0.5 \%$ is seen between $2010-2018$ where from 2010 there was economic growth of 3.31\% and 2018 of $3.81 \%$.

\subsection{Tax revenues in the budget composition}

The state collects revenues from its citizens and returns these revenues by providing them with services, such as: building roads, hospitals, schools, providing health, education and other services. The state collects revenues through tax revenues and non-tax revenues, and they are divided into:

- Designated donor grants

- Non-tax revenues

- Tax revenues

We will focus on the latter, i.e. tax revenues. Tax revenues represent all types of revenues that are in the name of tax.

Table 1: Revenues from the Tax Administration of Kosovo in the period 2011-2018

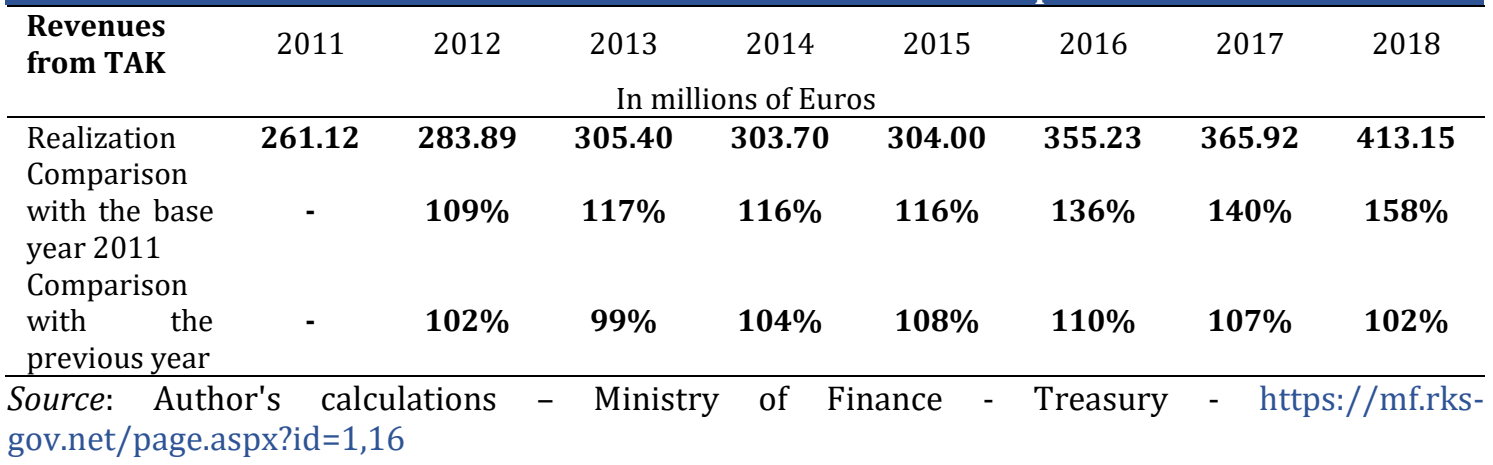

The table one presents the data of tax revenues from the Tax Administration of Kosovo and their comparison based on the base year 2011, as well as the previous year. Based on the data from the above table it can be seen that revenues from TAK have had a positive trend until 2018. Their value from year to year were as follows: 2011 provided 261.12mil, then in 2012 were provided 283.89 mil and that this increase was continuous in 2013 in the amount of 305.40 mil. Whereas 2014 resulted in a decrease and the value of revenues reached the value of $303.70 \mathrm{mil}$, while 2015 resulted in a relatively low increase of $304 \mathrm{mil}$. In 2016, the upward trend returns, reaching the value of collected revenues of $355.23 \mathrm{mil}$, then in 2017 the collected value reached the amount of $365.92 \mathrm{mil}$. In 2018 413.15mil were provided. 
The Kosovo budget divide tax revenues into direct revenues, indirect revenues and tax refunds. Direct taxes - are those taxes which are provided by the legislator, to bear the tax burden. Indirect taxes - are those which are not charged to the persons provided by the legislator but to other persons to whom the tax has been transferred.

\begin{tabular}{lcccccc}
\hline \multicolumn{7}{c}{ Table 2: Tax revenues in Kosovo in the period 2014-2019 } \\
\multicolumn{1}{c}{ Year } & $\mathbf{2 0 1 4}$ & $\mathbf{2 0 1 5}$ & $\mathbf{2 0 1 6}$ & $\mathbf{2 0 1 7}$ & $\mathbf{2 0 1 8}$ & $\mathbf{2 0 1 9}$ \\
\hline INCOME TAX & 1162 & 1269 & 1412 & 1496 & 1607 & 1731 \\
Direct taxes & 188 & 198 & 232 & 238 & 275 & 289 \\
Indirect taxes & 1007 & 1107 & 1227 & 1315 & 1378 & 1492 \\
Tax returns & -34 & -36 & -38 & -58 & -46 & -50 \\
\hline
\end{tabular}

Source: Author's calculations - Official Gazette of Kosovo - Law on Budget - https://gzk.rksgov.net/SearchIn.aspx?Index=2\&s=ligji\%20per\%20buxhet\&so=1

The table two presented above shows the data of tax revenues which are divided into direct taxes, indirect taxes and tax returns. The data of the table are taken from the official gazette of the Republic of Kosovo for the period 2014-2019. Based on the findings obtained during this study we have encountered a continuous increase in tax revenues which suggests that the tax system of Kosovo is working properly and taxpayers who are registered as such in the tax system are fulfilling their obligation to the state. In this table it is noticed that tax revenues in 2014 were $€ 1,162,000,000$ while 2019 provided an increase in the amount of $€ 1,607,000,000$. The highest amount recorded in direct tax revenues was that of 2019 with a value of $€ 289,000,000$ and the lowest value was in 2014 with $€ 188,000,000$. Increase in direct tax revenues was recorded throughout this period 2014-2019. In Indirect Taxes, there was an increasing trend where from 2014 these revenues were in the amount of $€ 1,007,000,000$ and in 2019 Indirect Taxes around $€ 1,492,000,000$. While the share of tax returns has no upward trend during this period, were 2014 marked the lowest value of $€ 34,000,000$, the following years recorded increases until 2017, were the highest value of tax returns of $€ 58,000,000$ was recorded, of the following year 2018 there was a decrease in terms of returns by $€ 46,000,000$, but that this value in 2019 increased by $€$ 4,000,000 which suggests that in 2019 tax returns were $€$ $50,000,000$.

\begin{tabular}{|c|c|c|c|c|c|c|}
\hline Year & 2014 & 2015 & $\begin{array}{c}\mathbf{2 0 1 6} \\
\text { In millions of Euros }\end{array}$ & 2017 & 2018 & 2019 \\
\hline Direct taxes & 188 & 198 & 232 & 238 & 275 & 289 \\
\hline $\begin{array}{l}\text { Corporate } \\
\text { income tax }\end{array}$ & 55 & 68 & 81 & 75 & 84 & 91 \\
\hline $\begin{array}{l}\text { Personal income } \\
\text { tax }\end{array}$ & 109 & 109 & 124 & 137 & 146 & 163 \\
\hline Property tax & 20 & 20 & 25 & 22 & 33 & 30 \\
\hline Other direct taxes & 4 & 2 & 2 & 3 & 12 & 4 \\
\hline
\end{tabular}

Source: Author's calculations - Official Gazette of Kosovo - Law on Budget - https://gzk.rksgov.net/SearchIn.aspx?Index=2\&s=ligji $\% 20$ per $\% 20$ buxhet\&so=1

The third table interprets the data on direct revenues in Kosovo. From the table we see that CIT in 2010 were $€ 55,000,000$ while in 2019 they reach $€ 91,000,000$ which results in an increasing and positive trend. Based on the analysis of data for TAP, we note that in 2010 there were $€$ $109,000,000$, while in 2019 they reach $€ 163,000,000$. Property tax in 2010 was $€ 20,000,000$, while in 2019 they reach $€ 30,000,000$. Other direct taxes in 2014 and 2019 were $€ 4,000,000$, in the years 2015-2016 were $€ 2,000,000$, in 2017 it reached $€ 3,000,000$ and in 2018 it reached the highest value of $€ 12,000,000$. From the table it can be seen that the trend of direct revenues marked an increasing and positive trend. 


\begin{tabular}{|c|c|c|c|c|c|c|}
\hline Year & 2014 & $\begin{array}{c}2015 \\
\text { In milli }\end{array}$ & $\begin{array}{l}2016 \\
\text { Euros }\end{array}$ & 2017 & 2018 & 2019 \\
\hline Indirect taxes & 1007 & 1107 & 1227 & 1315 & 1378 & 1492 \\
\hline Value Added Tax (VAT) & 560 & 611 & 694 & 756 & 819 & 905 \\
\hline Customs duty & 126 & 131 & 130 & 126 & 111 & 120 \\
\hline Excise & 315 & 361 & 403 & 432 & 446 & 465 \\
\hline Other indirect taxes & 6 & 3 & 0 & 1 & 2 & 2 \\
\hline $\begin{array}{l}\text { One-time income from tax } \\
\text { debt collection }\end{array}$ & 0 & 0 & 0 & 0 & 0 & 0 \\
\hline $\begin{array}{l}\text { One-time tax revenues } \\
\text { from debts to SOEs }\end{array}$ & 0 & 0 & 0 & 0 & 0 & 0 \\
\hline
\end{tabular}

Source: Author's calculations - Official Gazette of Kosovo - Law on Budget - https://gzk.rksgov.net/SearchIn.aspx?Index=2\&s=ligji\%20per\%20buxhet\&so=1

As we see on the basis of tabular data in Table 4, which presents the types and amount collected from Indirect Taxes in Kosovo during the time period 2014-2019. Revenues from VAT were $€ 560,000,000$ in 2014 and in 2019 amounted to $€ 905,000,000$. Revenues from customs duties in 2014 were 126,000,000, while in 2019 were $€ 120,000,000$. Despite the customs duties, the excise tax had an increasing trend all the time, where in $2014 € 315,000,000$ were collected from excises and in 2019 it was $€ 465,000,000$. Other indirect taxes from 2014 which were $€ 6,000,000$ decreased until 2016 where no other indirect revenues were recorded at all, then 2017 comes with an increase of $€ 1,000,000$ and the years 2018-2019 had the same value in terms of revenues other indirect of $€$ $2,000,000$. Even in indirect revenues, there is a positive and increasing trend of indirect revenues.

\subsection{Interpretation of econometric results of the OLS model}

In this subsection we interpret the econometric model results. While econometric models evaluate the impact of variables through: $\mathrm{T}$ - statistics and $\mathrm{P}$ - value (probability value); represents the exact level of significance: which indicates the relative power with which the null hypothesis can be rejected (Douglas, Elizabeth., \& Geoffrey, 2012).

\begin{tabular}{|c|c|c|c|}
\hline Model & Variables Entered & Variables Removed & Method \\
\hline $\begin{array}{l}1 \\
\text { a. Depe } \\
\text { b. All re }\end{array}$ & $\begin{array}{l}\text { Direct taxes, Indirect taxes } \\
\text { able: Gross Domestic Product } \\
\text { ariables entered. }\end{array}$ & . & Enter \\
\hline
\end{tabular}

Source: Author's calculations -Secondary data provided by the Kosovo budget, data over the years IBM SPSS program

Table 5 presents the conceptual variables used in the OLS model when GDP is dependent variable and direct and indirect taxes are independent variables.

\begin{tabular}{|c|c|c|c|c|}
\hline \multicolumn{5}{|c|}{ Model Summary } \\
\hline Model & $\mathbf{R}$ & R Square & Adjusted R Square & Std. Error of the Estimate \\
\hline 1 & ,789a & ,623 & ,372 & ,53882 \\
\hline
\end{tabular}

a. Predictors: (Constant), Indirect taxes, Direct taxes

Source: Author's calculations - Secondary data provided by the Kosovo budget, data over the years IBM SPSS program

In the Table 6 we interpret the determination coefficient $R$ that measure the importance of the model used. Based on the coefficient of determination it is seen that the model is important in our case the coefficient of determination $\mathrm{R}$ is 0.789 . The value of the coefficient of determination suggests that the model selected in this study is significant. 
Table7: The importance of variables in the model based on the p-value of the coefficients Coefficients

\begin{tabular}{|c|c|c|c|c|c|c|}
\hline & & Unstande & Coefficients & $\begin{array}{c}\text { Standardized } \\
\text { Coefficients }\end{array}$ & & \\
\hline & Model & B & Std. Error & Beta & $\mathbf{T}$ & Sig. \\
\hline 1 & (Constant) & 5,077 & 1,866 & & 2,721 & 072 \\
\hline & & ,011 & ,006 & 661 & 1,730 & 182 \\
\hline & Indirect taxes &, 000 & 001 & $-, 249)$ & $-, 651)$ & ,561 \\
\hline
\end{tabular}

Source: Author's calculations -Secondary data provided by the Kosovo budget, data over the years IBM SPSS program

The table seven presents the values of the coefficients of the variables in the model. We emphasize that the regression model modified and adapted in our study is multifactorial regression (OLS) where the dependent variable is defined Gross Domestic Product (GDP) and the independent variables that are expected to have impact on Gross Domestic Product are defined Direct Taxes (budget revenues from direct taxes) and the second independent variable in the model is Indirect Taxes (budget revenues from indirect taxes).

We present the importance of the variables according to the level of significance, specifically the importance of the variables measured by t-statistics and p-value. Based on the p-value of the variables we see that the first independent variable, namely direct taxes is not significant since the $\mathrm{p}$-value is 0.182 (the p-value condition less than 0.05 is not met in our case). The second independent variable defined in the model, namely indirect taxes is insignificant and does not explain the Gross Domestic Product since the $\mathrm{p}$-value is 0.561 . In cases where the independent variables result in a pvalue greater than 0.05 the effect of the variables is not explained, but is considered irrelevant in the model more specifically in the model conditions. We can conclude that in our case exactly in the model conditions the direct and indirect taxes have no impact on economic growth of Kosovo.

\begin{tabular}{llccc}
\hline \multicolumn{1}{l}{ Table 8: Pearson Correlation Matrix } & & & \\
Correlations & & GDP & Direct taxes & Indirect taxes \\
\hline GDP & Pearson Correlation & 1 & & \\
Sirect taxes & Sig. (2-tailed) & & \\
& Pearson Correlation &, 755 & 1 & \\
Indirect taxes & Sig. (2-tailed) &, 083 & & \\
& Pearson Correlation & $(-, 497)$ & $(-, 375)$ & 1 \\
& Sig. (2-tailed) &, 316 &, 463 & \\
\hline
\end{tabular}

Source: Author's calculations - Secondary data provided by the Kosovo budget, data over the years IBM SPSS program

In the table eight we present the Pearson Correlation Matrix. Based on the importance of the Pearson coefficient that measures the relationship between only two variables where the coefficient takes values from -1 to +1 the value of the Pearson coefficient close to -1 results in negative correlation between the two variables from 0 to +1 the relationship between the variables is positive. Specifically as close to +1 the value of the Pearson coefficient results that the relationship between the two variables considered is a strong and in positive relationship.

From the above table we see that Gross Domestic Product (GDP) is strongly and positively correlated to the direct tax variable in the value of the Pearson coefficient 0.755 while GDP is negatively correlated to the indirect tax variable at the level of Pearson coefficient (-0.497). The direct tax variable is negatively related to the indirect tax variable in the Pearson coefficient value (0.375).

\section{Conclusions and recommendations}

The tax system should not distort the principle of efficiency which is seen as the basic principle of a tax system. A proper tax system should be transparent, simple, and consistent and minimize distortions of taxpayer behavior. It must be neutral as well as fair between different types of taxpayers in similar economic situations. 
The tax system of Kosovo and its impact on economic growth, despite the fact that it is a new state, has managed to create a very stable tax system and has also managed with the tax system it's become quite competitive with other countries in the region, in terms of low tax rates. Kosovo still has a lot of work to do to secure higher tax revenues in order to secure its budget as a country that wants to join the EU.

From the aspect of tax policy as well as the professional one of the tax authorities, tax reforms are definitely necessary. In order for the implementation of tax reforms to be as effective as possible, continuous employment of staff to meet the prerequisites such as: to ensure professional training of TAK staff by organizing various trainings with international experts; awareness of taxpayers or the principle of self-declaration; also to provide institutional infrastructure, etc. good form of reducing tax evasion, corruption and informality by businesses is to increase the opportunity and forms of fiscal control exercised by regulatory bodies and state institutions. Drafting long-term political strategies in the fight against informality, finding a common language on issues of common interest, highlighting the negative aspects of informality, etc. can be effective ways to reduce the phenomenon of informality. Building fiscal policies in such a way as to encourage investment by local and foreign investors would enable economic development. The support of start-ups and existing ones in their development and growth by state bodies would have a positive effect in terms of increasing tax revenues and increasing the state budget.

\section{Citation information}

Ziberi, B., \& Hodaj, A. (2020). The fiscal policy and economic growth of Kosovo: An econometrical analysis. Economics, Management and Sustainability, 5(2), 112-121. doi:10.14254/jems.2020.5-2.8

\section{References}

Aghion, P., \& Marinescu, I. (2008, June). Cyclical Budgetary Policy and Economic Growth: What Do We Learn from OECD Panel Data? National Bureau of Economic Research, vol 22, 251-278.

Alesina, A., \& Ardagna, S. (1998, October 1). Tales of fiscal adjustment. Economic Policy, 13(27), 488545.

Babbie, E. R. (1998). The Basics of Social Research.

Barro, R. J. (1979, October). On the Determination of the Public Debt. The University of Chicago Press Jornual, 87 (5, Part 1), 940-971.

Barro, R. J., \& Sala-I-Martin, X. (1992, October). Public Finance in Models of Economic Growth. The Review of Economic Studies, vol 59(No. 4), 645-661.

Bertola, G., \& Drazen, A. (1993, March). Trigger Points and Budget Cuts: Explaining the Effects of Fiscal Austerity. NBER Working Paper, vol 83, No. 9, 11-26.

Douglas, M., Elizabeth., P., \& Geoffrey, V. (2012). Introduction to Linear Regression Analysis (Fourth Edition ed., Vol. 821). John Wiley \& Sons.

Gentry, W. M., \& Ladd, H. F. (1994). STATE TAX STRUCTURE AND MULTIPLE POLICY OBJECTIVES. National Tax Association, 47, 747-772.

Gjokutaj, E., \& Gjokutaj, A. (2019, June). Fiscal burdens in Albania, Kosovo and the Western Balkans. 2019. Research Gate.

Hayek, F. A. (1932). Prices and Production (2nd ed.). London: George Routledge and Sons, LTD.

Krasniqi, M. (2016). Management of fiscal policies and their impact on the economic development of a country (with a view to Kosovo 2008-2012). Retrieved from www.uet.edu.al: http://uet.edu.al/images/doktoratura/Malush_Krasniqi.pdf

Mark, H., \& Asmaa, E.-G. (2009, June). Back to Basics: What Is Fiscal Policy? International Monetary Fund, 46, No. 2, 82-83.

Musgrave, R. A. (1959, December 1). The Theory of Public Finance. The Economic Journal, Vol. 69(276), 766-770. 
Reports No.83975-XK. (2014). Kosovo Public Finance Review - Fiscal Policies for a New State. Poverty Reduction and Economic Management Unit - Europe and Central Asia Region. Pristina: The World Bank.

Samuelson, P. (1954, Novembre). The Pure Theory of Public Expenditure. The MIT Press, 36(4), 387389.

Schinasi, J. G. (2004). Defining Financial Stability (Vol. No. 04). (I. M. Fund, Ed.) Working Paper.

Spilimbergo, A., Schindler, M., \& Symansky, S. A. (2009). Fiscal Multipliers. International Monetary Fund (Issues 2009-2011 of IMF Staff Position Notes), 2-6.

Stiglitz, J. E. (2014, May 28). Reforming Taxation to Promote Growth and Equity. Roosevelt Institute.

Stiglitz, J. E., \& Boadway, R. W. (1994). Economics \& the Canadian Economy. W W Norton \& Co Inc.

Tax Administration of Kosovo. (2000). General information on taxes in Kosovo. Retrieved April 2020, from http://www.atk-ks.org/portfolio/informata-te-pergjithshme-per-tatimet-ne-kosove/

Tax Administration of Kosovo. (2000). About TAK. Retrieved 2020, from http://www.atk-ks.org/.

Tax Administration of Kosovo. (2014). Law on Tax Administration and Procedures.

Woo, J. (2009, April 23). Productivity growth and technological diffusion through foreign direct investment. Wiley, 47(2), 226-248.

Ziberi, B., \& Avdiu, M. (2020). Econometric analysis to examine the relationship between unemployment and macroeconomics aggregates. Evidence from Kosovo. Academic Journal of Economic Studies, 6(2), 33-41.

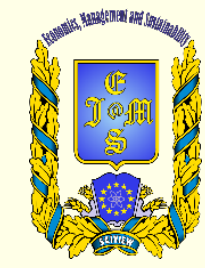

(๑) 2016-2020, Economics, Management and Sustainability. All rights reserved.

This open access article is distributed under a Creative Commons Attribution (CC-BY) 4.0 license.

You are free to:

Share - copy and redistribute the material in any medium or format Adapt - remix, transform, and build upon the material for any

purpose, even commercially.

The licensor cannot revoke these freedoms as long as you follow the license terms.

Under the following terms:

Attribution - You must give appropriate credit, provide a link to the license, and indicate if changes were made.

You may do so in any reasonable manner, but not in any way that suggests the licensor endorses you or your use.

No additional restrictions

You may not apply legal terms or technological measures that legally restrict others from doing anything the license permits.

Economics, Management and Sustainability (ISSN: 2520-6303) is published by Scientific Publishing House "CSR",

Poland, EU and Scientific Publishing House "SciView", Poland

Publishing with JEMS ensures:

- Immediate, universal access to your article on publication

- High visibility and discoverability via the JEMS website

- Rapid publication

- Guaranteed legacy preservation of your article

- Discounts and waivers for authors in developing regions

Submit your manuscript to a JEMS at http://jems.sciview.net or submit.jems@sciview.ne

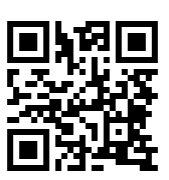

